CIRCULAR EYE-TRACKING TEST (CETT)

-THE SECOND REPORT-

FROM A CONSIDERATION OF 55 CASES WITH CENTRAL DISORDERS.

YOSHIO UMEDA, M.D., EIJI SAKATA, M.D., AND KYOKO ÔTSU.

Department of Oto-rhino-laryngology, Tokyo Rôsai Hospital, Tokyo

In the preceding paper, the authors presented the Circular Eye-Tracking Test as one of new approaches in vestibular examination. This test was performed by an apparatus in which the visual stimulus moved drawing a circle clock-wise at $120 \% / \mathrm{sec}$ with the radius of $25.5 \mathrm{~cm}$. The apparatus was set $70 \mathrm{~cm}$ before the patient, whose eye movements pursuing a visual stimulus were recorded by ENG.

With an accumulation of our experiments, the authors could reaffirm two good advantages of the Circular Eye-Tracking Test; simultaneous recording of the horizontal and vertical components of eye movement pursuing a visual stimulus, and decrease of the artifacts by the movement of upper eyelids which often appeared in the vertical eye-tracking test.

In this study, 55 cases with central disorders were examined by the Circular Eye-Tracking Test and 23 cases showed abnormal eye movement. We classified them into three groups as follows:

i) abnormalities found mainly in the horizontal component ( 6 cases of congenital nystagmus and 1 case of post traumatic normal pressure hydrocephalus).

ii) abnormalities found mainly in the vertical component ( 6 cases including: basilar impression+ Arnold Chiari's malformation + platybasia + scoliosis, and Wernicke's encephalitis).

iii) abnormalities found both in the horizontal and vertical components (10 cases including plstybasia + Arnold Chiari's malformation + basilar impression + syringobulbia, and late cerebellar cortical atrophy),

In any of these three groups, the central spontaneous nystagmus was always superimposed on the pursuit movement in the Circular Eye-Tracking Test.

The data presented here are not sufficient to affirm that the abnormalities of the horizontal and vertical components in the Circular Eye-Tracking Test are directly related to the lesions at the locations controlling horizontal and vertical eye movements respectively. But it should be noted that in not a few of these cases we found coincidence between the physiopathological lesions and abnormalities recorded by the Circular Eye-Tracking Test

\author{
A 78-0316. 25522 \\ 円運動視標追跡検查 (Circular Eye Tracking Test; CETT) \\ 2. 中枢疾患 55 例にもとゔく検索結果から \\ 東京労災病院耳鼻咽喉科 (院長: 近藤駸四郎博士) \\ 梅田悦生・坂田英治·大都京子 \\ Iはじめに \\ Tracking Test (以下 CETT と略す) を開発し，前号で \\ 発表した”。 \\ その後も，さらに症例を重ね，運動視標追跡検查にお
}

新しい平衡機能検査のひとつとして，著者らは視標が

円を画いて動く，円運動視標追跡検查 Circular Eye 
いて，本検查法を用いることにより追跡運動の水平成分 と垂直成分とを同時に記録することができること，ま た, 従来の垂直性運動視標追跡検查の欠点のひとつであ つた上眼瞼の動きに伴う artifact を軽減できることを確 認しえた.

今回は CETT を行つた中枢疾患55例について，追跡 運動の異常を見出しえたものを分析し，次のようにろつ に分類した.

すなわち，まず CETT の水平成分に主として異常を 認めるもの, つぎに, 垂直成分に主として異常を認める もの，そして水平成分垂直成分ともに異常を認めるも の,の3つである.

\section{(i) 方法}

\section{－ＩI 方法ならびに対象}

検查法は，すでに発表したごとく1) 視標が半径（視 角) $20^{\circ}$ の円を描いて，每秒 $120^{\circ}$ の定速で時計方向に まわる CETT 装置を用い, その眼球運動を ENG によ り記録した。

(ii) 対象

症例としては, 昭和 49 年 2 月 2 日から同年 5 月 1 日ま
での間に，東京労災病院前庭外来を訪れた患者のうちか ら, 手術または神経学的, 神経耳科学的に, かなりの確 かさをもつて，その障害部位の確かめられた中枢疾患55 例を選んだ.

その内訳は (1)中枢前庭障害46例；すなわち，いわゆ る 莖性眩最 7 例, 先天性特発性眼振 6 例, 椎骨脳底動脈 不全症 5 例, 小脳萎縮 4 例, 血管性中脳障害 4 例, 頭蓋 底陥入症とその合併症 4 例, てんかん 2 例, 薬物中毒 2 例（トルオール中毒, テグレトール中毒各 1 例）ほか， 後大脳動脈瘤, 椎骨動脈狭窄, 中脳水道周囲症候, 小児 麻㾝十潜伏眼振, 多発性硬化症を疑 5 脳幹障害, 左小脑 障害, 小脳虫部障害, 頭部外傷による脳幹障害, パーキ ンソニスム, 血管性内包障害, 血管性天幕下障害, 左側 頭葉陥没骨折各 1 例, また (2)中枢前庭障害十末梢前庭 障害 9 例; すなわち，メニエール氏病十中枢性血管障害 3 例, 、わゆる突発難聴十血管性脑幹障害 3 例, 内耳梅 毒十頸性眩最 1 例, 急性ストレプトマイシン中毒 1 例, 急性内耳機能廃絶症十小脳障害を疑うもの 1 例である.

\section{III 結 果}

(i) CETT で水平成分に異常を認め，垂直成分はほ

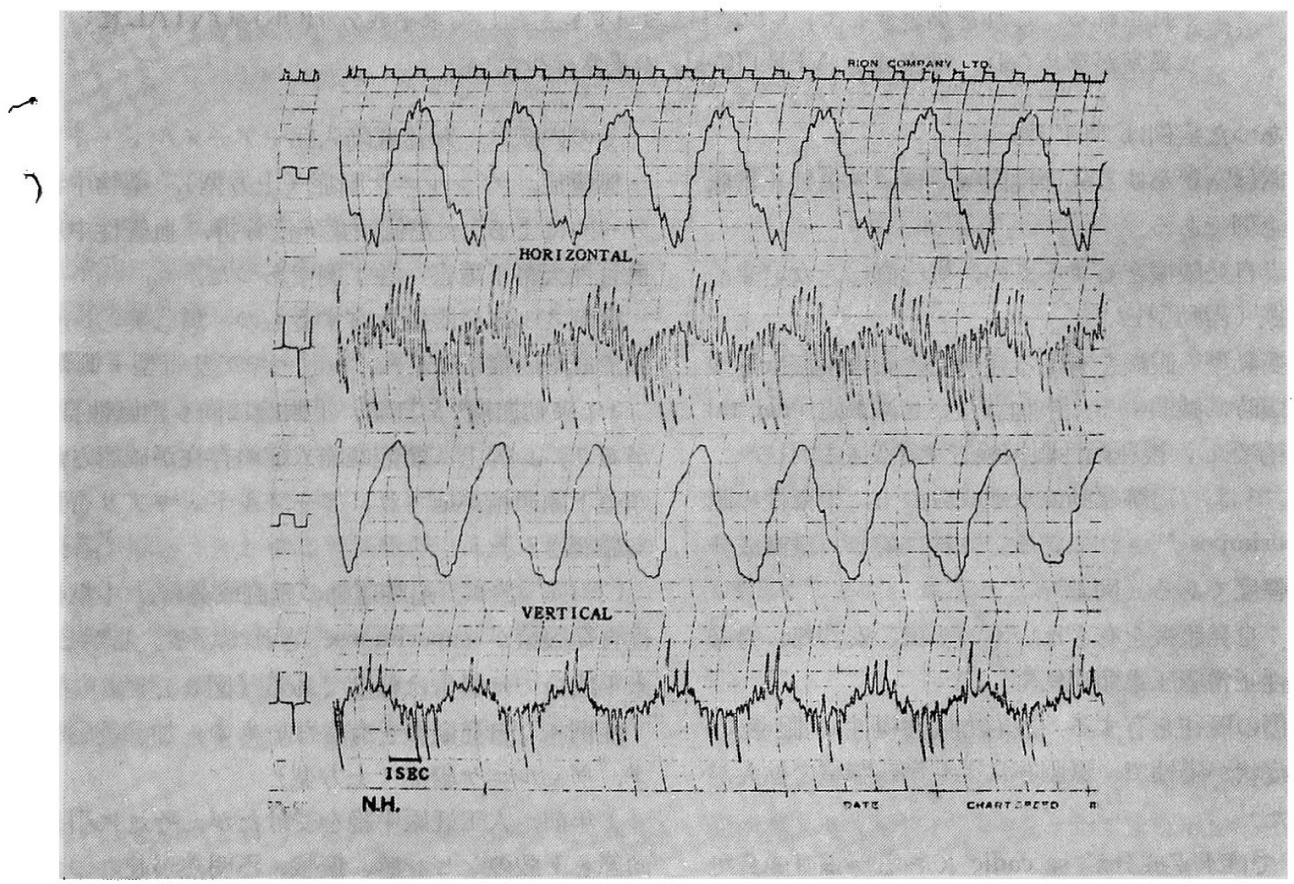

図 1 症例1。 N.H., 女21才，先天性眼振（衝動型），中枢性の水平眼振が CETT の水平誘 遒, すなわち追跡運動の水平成分 HORIZONTAL に superimpose されている. 垂直 誘導, すなわち追跡運動の垂直成分 VERTICAL の異常は㹩度である. 


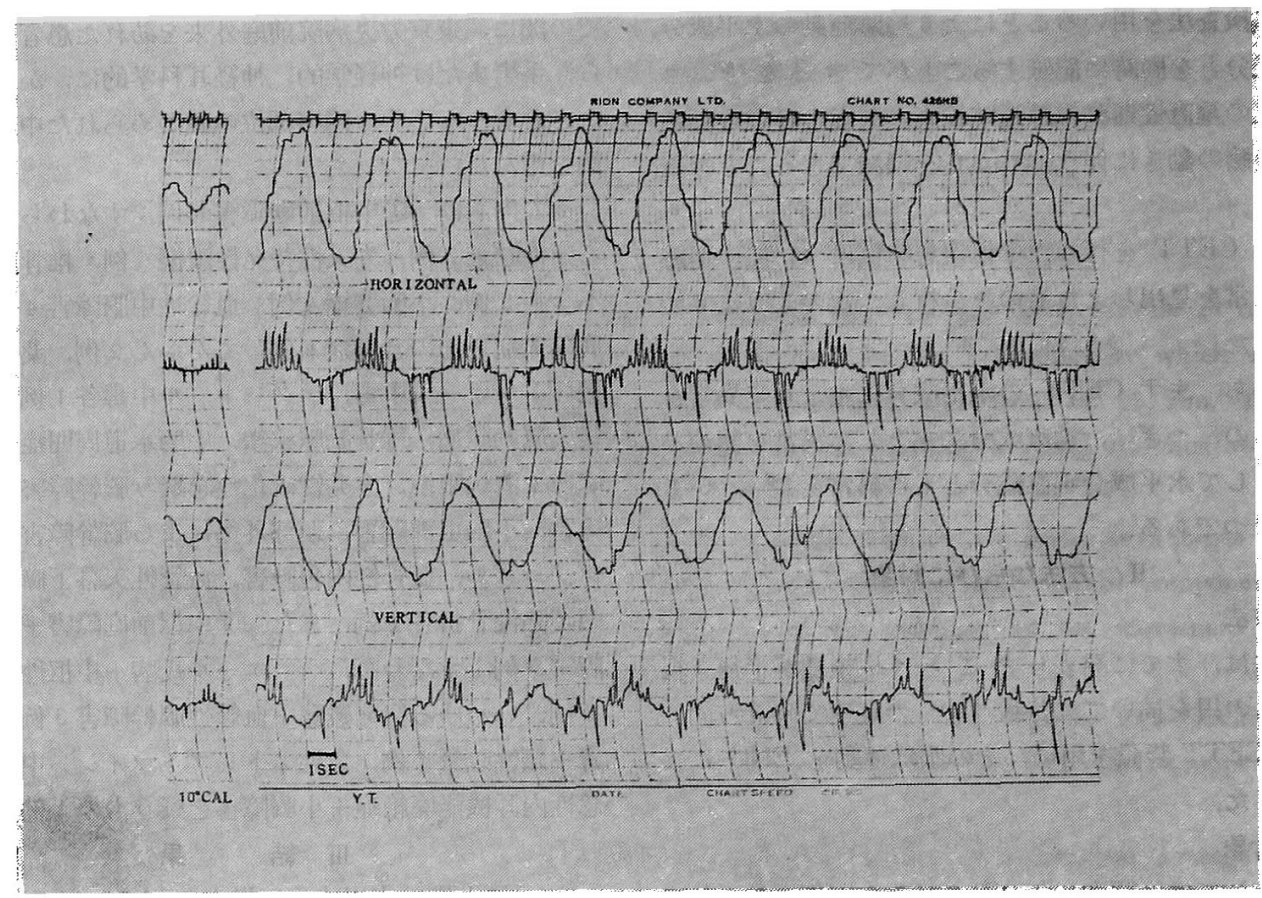

図 2 症例2. Y.T., 男48才, 外傷性正常脳圧水頭症. 神経耳科的には小脑室頂核の障害が注 目される.これを裹書きして，CETTにおいても主として水平成分 HORIZONTALに 異常が認められ，垂直成分 VERTICAL の異常は少ない

ぼ正常であつた症例は 7 例であつた.

その内訳は, いわゆる先天性眼振 6 例, 外傷性正常脳 圧水頭症 1 例である。

症例 1 : 自発眼振を有するもの, 堀○直○, 女21才, 先天性眼振 (衝動型) $)^{2)}$

水平性衝動型の眼振を有する症例で, この眼振は閉眼 および遮眼時に減弱する. 中和点ないし減弱点 (neutral point）が存在し，視運動性眼振検査で錯倒を呈する.

CETT では, 追跡運動の水平成分の上に中枢性の眼

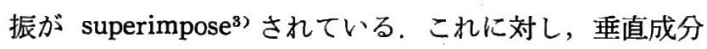
の異常は軽度である(図 1 )。

症例 2 : 自発眼振を有さないもの, 田○安○郎, 男48 才, 外傷性正常脳圧水頭症 ${ }^{4}$

頭部外傷の既往を有する. 左右方向注視性の眼振の 他, 小脳症状が陽性で, 気脳写により第四脳室の扡大が 認められた。

CETT では水平成分が saccadic であるが垂直成分で は異常は軽度である(図 2 )。

(ii) CETT で垂直成分に異常を認め，水平成分はほ ぼ正常な症例は6例であつた。
その内訳は, 頭蓋底陷入症+アーノルド キアリ奇型 十側彎症, ヴェルニケ脳症 (上方型), 薬物中毒 (トル オールによる), 左側頭葉陥没骨折, 血管性中脳障害, 血管性天幕下障害, 各 1 例であつた.

症例 3 : 自発眼振を有するもの 馬 $\mathrm{O}$ 美 $\mathrm{O}$, 女13才,

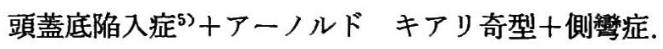

3年来動摇視 ${ }^{6}$ を自覚. 下眼瞼に向 5垂直性自発眼振 ${ }^{7)}$ があり, レ線上, 頭蓋底陷入症の存在が確認される. 後 頭蓋下開頭術が施され, アーノルド キアリ奇型の合併 毛確認された。

CETT では, 追跡運動の垂直成分に, 中枢性の垂直 性自発眼振が superimpose されている.しかしながら， 水平成分では異常は軽度である(図 3 ).

症例 4 : 自発眼振を有さないもの. 加○美○子, 女30 才, ヴェルニケ脳症 (上方型).

1 年前, 人工妊娠中絶を受けたが, それに引き続き, 頭部と下肢のシビレ感, 振戦, 不明熱が起こつた、体位 変換時に眼前暗黒感がある。数週間前から, 発熱, 手の 振戦を訴える.上方注視で下方に向ら眼振様運動が見ら れ，輻輳も不充分である。これらのことから，上部这幹 


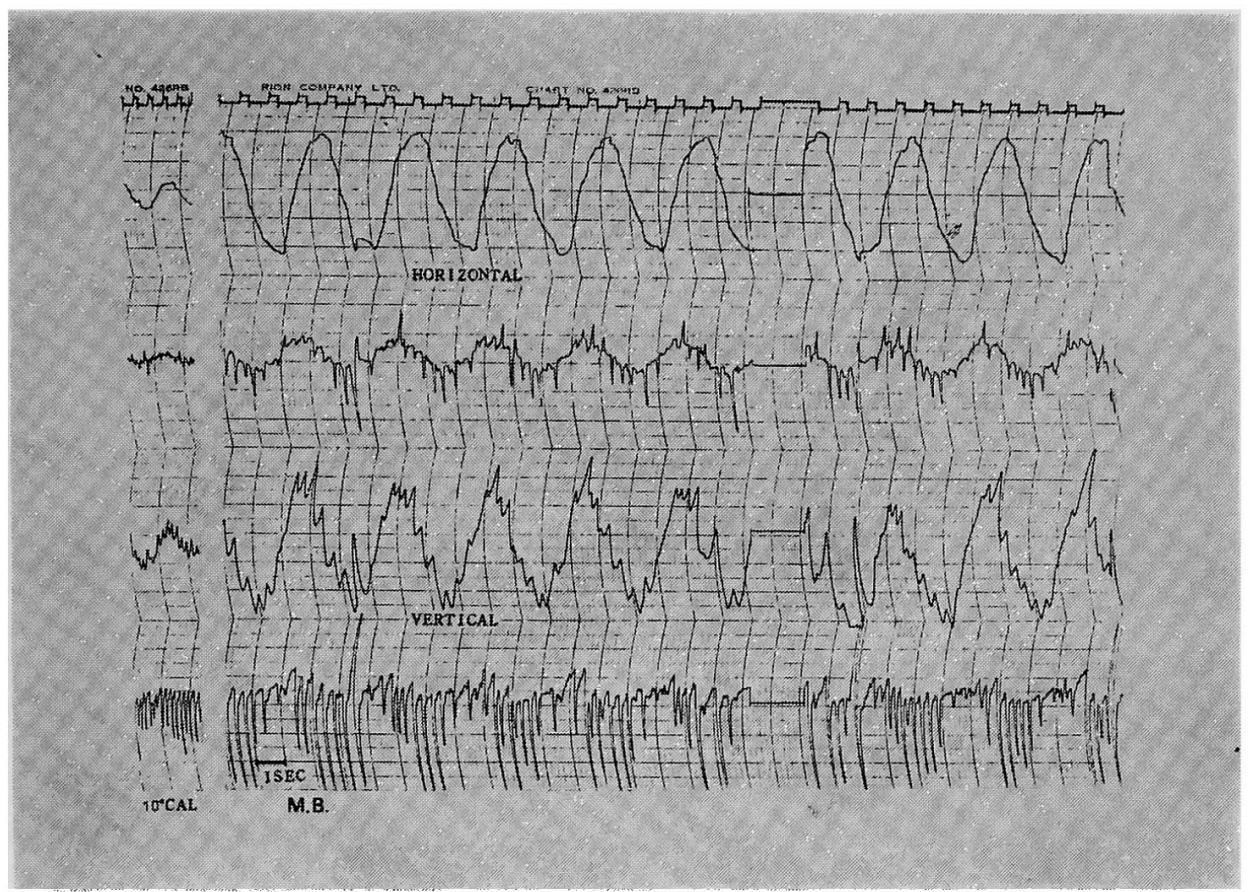

图 3 症例 3. M.B.女13才, 頭蓋底陥入症+アーノルド・キアリ奇型十扁平頭蓋底+側彎症. 下眼瞼に向ら垂直性自発眼振が，垂直誘導でとらえた追跡運動の垂直成分VERTICALに superimpose されている. しかし水平成分 HORIZONTAL の異常は軽度である.

\section{の障害が疑われた.}

CETT では，垂㨁成分に軽度ではあるが明らかに， しかも恒常的に追跡運動の障害を認める. 反面, 水平成 分には異常を認め得ない（図 4).

(iii) CETT で垂直成分にも，水平成分にもともに著 しい異常を認める症例は10例であつた.

その内訳は, 亜急性晚発性小脑萎縮症, 内包障害によ る片麻盘，てんかん十薬物中毒（テグレトールによる）， 血管性天幕下障害十いわゆる突発難聴, 広汎な脳幹障害 を疑 ゆる突発難聴, 頭蓋底陥入症十小脳変性症, 頭蓋底陥入 症十延髄空洞症, 頭蓋底陥入症十アーノルド キアリ奇 型十扁平頭蓋底, 血管性脳幹障害十突発難聴, 各 1 例で ある。

症例 5 : 自発眼振を有するもの. 茂○と○子, 女 38 才, 頭蓋底陥入症十扁平頭蓋底十延髅空洞症の合併.

動摇視, 下眼臉向き垂直性自発眼振, 言語障害, 右上 肢運動不全麻㾝, 右上頸部知覚解離, 歩行障害など臨床 的にも这幹下部を中心とした障害が考えられる. 頭部レ
線像により, 頭蓋底陥入症, 扁平頭蓋底が確認された。 CETT では追跡運動の垂直成分に，垂直性自発眼振 が重なつている。 また, 水平成分でも異常を認める（図 5 ).

症例 6 ：自発眼振を有さないもの. 松○重 $\bigcirc$ 郎, 男70 才, 亜急性晚発性小脳萎縮症 ${ }^{8)}+$ 脳動脈硬化症.

歩行障害, 言語障害ほか著明な小脳症状を呈する。物 忘れがひどく，最近性格が変わつてきた，また，方向注 視性水平性眼振が観察される.

CETT では, 垂直, 水平成分ともに, 追跡運動の障 害がみられる（図6).

\section{IV 考察}

CETT に異常を認めたものは，55症例中23例あり， その内訳は，(i)主として水平成分 HORIZONTAL に異 常を認めたもの 7 例, (ii)主として垂直成分 VERTICAL に異常を愨めたもの 6 例, (iii)水平・垂直成分ともに異常 を認めたものは10例であつた. いずれの場合にも，中枢 性の自発眼振は CETT 上にも superimpose されてい た. 

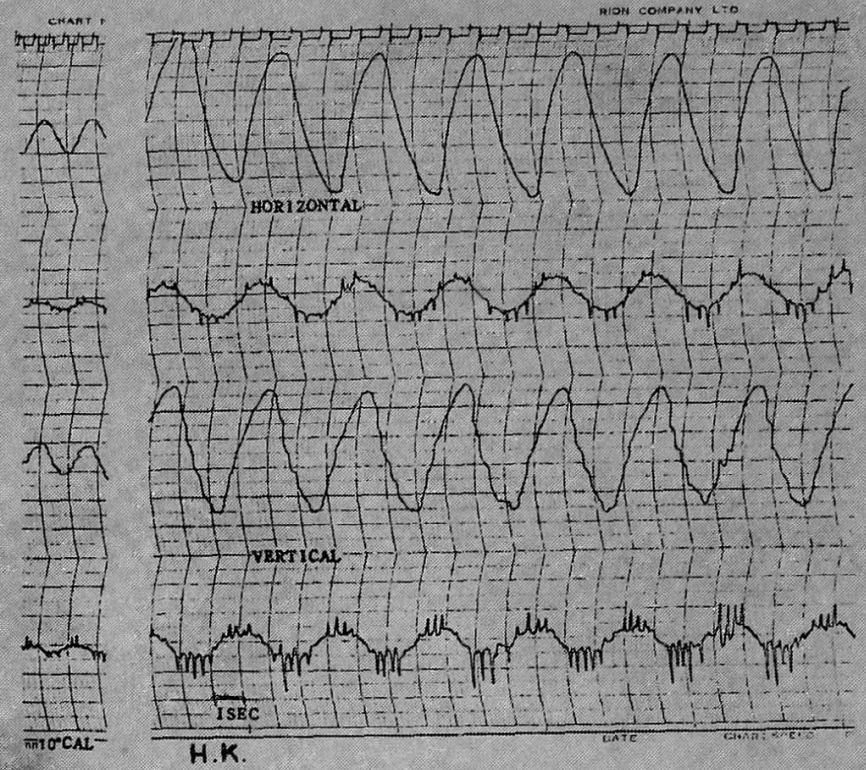

图 4 症例 4. H.K. 女30才，ヴェルニケ脳症(上方型). 垂直成分 VERTICAL に軽度ではあ るが恒常的に異常をみとめる. 水平成分 HORIZONTAL は正常といえる.

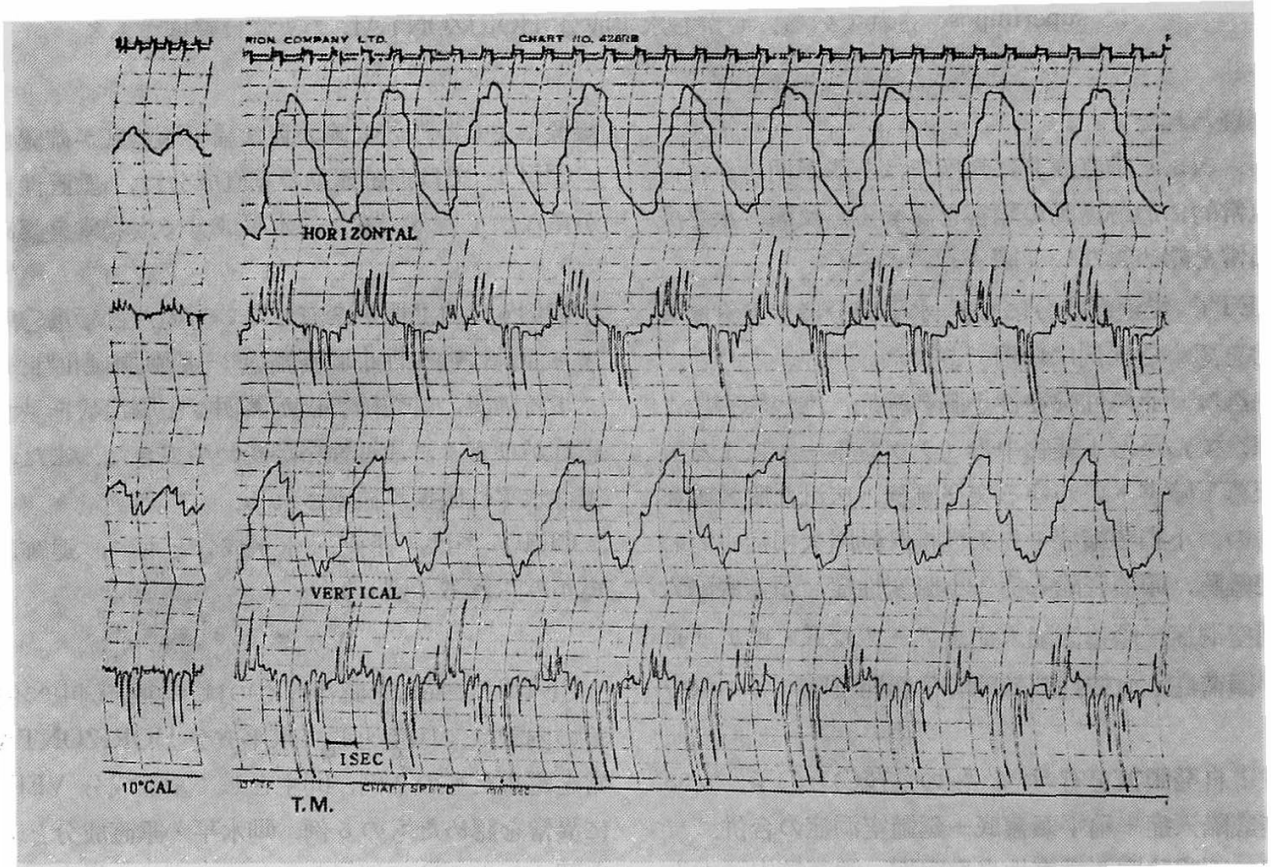

図 5 症例 5. T.M., 女38才, 頭蓋底陥入症十アーノルド・キアリ奇型十扁平頭蓋底+延檤空洞症. 右下方一向5垂直性自発眼振を有する。垂直成分 VERTICAL，水平成分 HORIZONTAL ともに異常をみとめ, 図 3 と比較しその障害部位がより広範囲であることが推定される. 


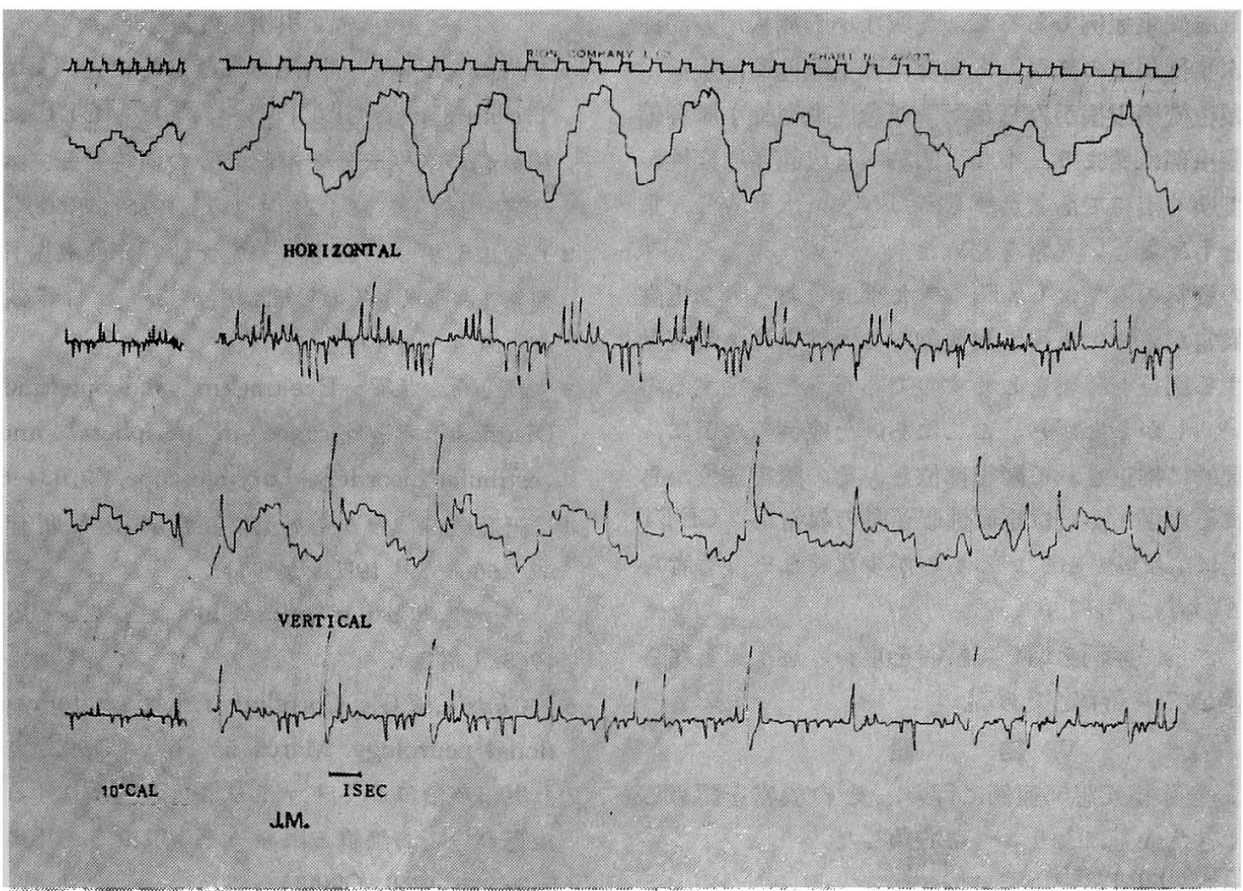

図 6 症例6. J.M., 男70才。亜急性晚発性小脳萎縮症十脳動脈硬化症. 水平成分 HORIZONTAL, 垂直成分 VERTICAL ともに明らかな異常をみとめ, 障害が軽度のものでない ことが考えられる.

CETT で水平成分に明らかな異常を認め, 垂直成分 の異常は軽度であうたものは症例 1 を含めた先天性眼振 6 例（衝動型 5 例，振子・衝動型 1 例, ともに眼振は水 平性）と外傷性正常腦圧水頭症 1 例である. 症例 1 を含 め, 先天性眼振例はすべて, 中枢性の水平性自発眼振が CETT の水平成分に superimpose されている. しかし ながら垂直成分の異常は轻度である. 症例 2 は, 外傷性 正常脳圧水頭症加神経学的にも気脳写に招いても確認さ れた症例であるが，眼振は水平性のものしかみられなか つた. CETT でも，主として水平成分に異常がみられ， 垂直成分には軽度の上眼瞼による artifact と考えられる ものの混入のほか著しい異常はみられない，

さて，CETT で垂直成分に異常を認め水平成分での 異常は軽度であつたものは 6 例あつたが，それらの障害 部位は上部脳幹 2 例, 下部脳幹 1 例, 錐体外路 2 例, 天 幕下といえるもの 1 例であつた，症例 3 は, 頭蓋底陥入 症でアーノルドロキアリ奇型を伴つたものであり，下眼 瞼に向ら垂直性自発眼振が追跡運動の垂直成分に superimpose されているが，水平成分の異常は軽度である。
症例 4 では，上方注視時に下方に向う垂直性眼振が観察 され，輻軼も不充分であり，中这の高さでの障害が考え られるが, CETT でも 事実, 垂直成分にのみ異常がみ られ興味深、

CETT の垂直成分にも水平成分にも異常を認めたも のは10例あつたが，それらのもののいくつかは，天幕下 領城にかなり広範囲な障害があるものと考えられる症例 であつた，症例 5 では，やや右方に向与解離性の下眼瞼 向き垂直性自発眼振が観察され，頭部レ線により，軸椎 の歯状突起は上方に著しく突出しており，しかも基底角 は広く, 頭箇底陥入症々扁平頭蓋底の合併が明らかであ つた。 さらに右第 2 , 第 3 頸神経領域での分離性知覚麻 㾝, 右第IX, X脳神経の軽度の障害などから延㵦空洞症 の合併も疑われた。本症例は, 症例 3 と異り延葡空洞症 の合併があるため，ETT の水平成分にも異常があるだ 万らと予想された。事実, CETT では垂直成分に中枢 性眼振が superimpose されたのみならず，水平成分にも saccadic な異常をみることができた，症例 6 では，外傷 の既往をもち, 精神症状む伴亏, 亜急性晚発性小脳萎縮 
症十媨動脈硬化症例であるが，著明な小脳症状，方向注 視性の水平性眼振のほか, 方向交代性上向性頭位眼振, 垂直性頭位変換眼振がみられた. 亜急性晚発性小脳萎縮 症は小脳虫部に始まり，中脳，間脳一と広範囲に変性が およんでゆく知患であるが，CETTでは水平成分，垂 直成分ともに著しい異常を認めた.

以上の資料のみで，CETT の水平成分あるいは垂直 成分の異常が直ちに水平性眼運動あるい忙垂直性眼運動 に関与する部位の障害をしめすのであるらと断定するの ではない.しかしながら、ここにあげた症例のなかに， 病態生理的に推定される障害部位と，その障害部位から 考えられる水平あるいは垂直性眼運動の異常が，CETT の記録上にも反映されているものが少なくない，著者ら は現在この点に注目している。

今後, さらに症例を增して検矿を重ね，逐次報告なら びに論述してゆく予定である。

$$
\mathrm{V} \text { 結 語 }
$$

CETT を中枢疾患55症例に行い，その異常を認める ことができた成分により3つに分類した。

すなるち, CETTの

(i) 主として水平成分に異常を認めたものは先天性眼 振, 外傷性正常脳圧水頭症など 7 例

(ii) 主として垂直成分に異常を認めたもの頭蓋底宿 入症ナアーノルド・キアリ奇型十扁平頭蓋底十側禁症, ヴェルニケ脳症など 6 例

(iii) 水平成分，垂直成分ともに異常を認めたものは頭 蓋底陌入症十アーノルド * キアリ奇型十肁平頭蓋底十延 榷空洞症など10例であつた。

いずれの場合む，中枢性の自発眼振は CETT の追跡 運動に superimpose されていた。

\section{引用文献}

1) 梅田说生和：円道動視標追跡検查（Circular Eye Tracking test; CETT) 一その1-ETTにおける追 跡運動の水平成分と垂直成分の同時記録，artifact の 軽城。日耳 $78 ; 218-224,1975$ (昭50)

2）栄木恭男：いわ的る「先天性特発性服振」の病態生 理補遗一106症例の検索結果から一。 日耳鼻, $77 ; 8-$ 45, 1974. (昭49).

3) Benitez, J.T.: Eye-tracking and optokinetic tests: Diagnostic significance in peripheral and central vestibular disorders. Laryngoscope, 80;834-848, 1970.

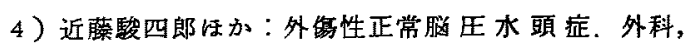
$32 ; 666-672,1970$. (昭45).

5 ）金子寛：Basilar Impression. 日耳鼾，68；231-243, 1965. (昭40).

6) Chusid, J.G.: Correlative neuroanatomy and functional neurology. Maruzen, Tokyo, 1973.

7）坂田英治洼か：メマイ・平衡障害における眼球運動 検查の猃断的価值と限界一之の現段階一耳監，61； 543-562, 1968. (昭43).

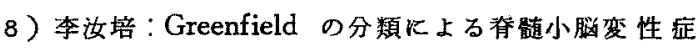

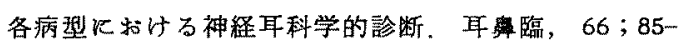
112, 1973. (昭47).

稿を䅂るにのそみ，御指導，御校閲を睗つた東京学苂 病院長近藤駿四郎博士, 帝京大学医学部耳艒咽㬋科学教 室教授鈴木淳一博士に灌しんで深謝します。

本諭文の要旨は，第33回日本平衡神経科学会（春季学 会）に招いて発表した.)

（原稿受付 昭和49、7、30日） 